\title{
Diagnóza F 64.0: Transsexualita optikou sexuologie
}

\author{
Diagnosis F 64.0: Transsexuality from the Sexological Point of View \\ Jana Dvořáčková
}

\begin{abstract}
This text is an analysis of discourses through which the discipline of sexology, particularly in the context of the Czech Republic, conceptualizes transsexuality. Based on the analysis of selected documents, the paper aims to map the essential turning points in the development of the sexological etiology of transsexuality. It also aims to identify the gender assumptions in which this conception of the etiology of transsexuality is embedded. The second part of the paper focuses on how sexological preconceptions of gender and sexuality form conventions of standardized diagnostic procedure, its singular techniques and its criteria for confirming or, on the contrary, disproving the diagnosis of transsexuality. The sexological discourses of transsexuality are theorized from a poststructuralist perspective, which accents the formative aspects of social discourses, and above all the discourses of science.
\end{abstract}

KEY WORDS gender norms, norms of sexuality, sexology, transsexuality

\section{1. Úvod}

Počátkem 20. století, kdy lékařská věda nachází v lidském těle další a další klíče k tomu, co údajně dělá muže mužem a ženu ženou, kdy slaví úspěchy s objevem pohlavních chromozomů a závratným tempem rozvíjí poznatky v oblasti pohlavních hormonů, tedy v době, kdy se vše zdá nasvědčovat tomu, že konečné vysvětlení „odlišnosti““ už musí být na dosah, se začínají objevovat také lidé s dříve nepozorovaným problémem. Navzdory tomu, že jejich těla, jak se zdá, neodporují nijak oněm nejnovějším vědeckým poznatkům, nebot’ nevykazují žádné anatomické, chromozomální ani hormonální nesrovnalosti, sužují tyto osoby pocity, pro které nemá stávající medicínský výkladový aparát k dispozici žádné uspokojivé vysvětlení - cítí se být př́islušníky či příslušnicemi „opačného“ „pohlaví““.

Sociální studia. Fakulta sociálních studií Masarykovy univerzity, 1/2008. S. 55-75. ISSN 1214-813X.

1 Páteř, o niž novodobá medicína opírá svůj výklad pohlavní/genderové diference - triáda tvořená pohlavními žlázami, chromozomy a hormony -, má své počátky v 18. století, kdy je už nejen definitivně potvrzena odlišnost varlat a vaječníků, ale kdy se zároveň o těchto orgánech začíná smýšlet jako o původcích rozdílů mezi mužem a ženou (Laqueur 1990). K objevu pohlavních chromozomů dochází počátkem 20. století (Kessler a McKenna 1985), tedy přibližně ve stejné době, kdy se podle Fausto-Sterling (2000) rozvíjejí poznatky o posledním z členů triády - pohlavních hormonech. První známé př́ípady „opačné“ genderové sebeidentifikace pak bývají situovány do období přelomu 19. a 20. století (Bullough 1994, Procházka a Weiss 2002). 
Sexuologie sehrává v konstruování transsexuality aktivní roli od samého počátku právě v sexuologii totiž dochází k ustavení transsexuality jakožto svébytné kategorie s jistými charakteristickými projevy. Děje se tak během prvního desetiletí 20. století, kdy německý sexuolog Magnus Hirschfeld začíná odlišovat homosexuály a lesby, u nichž pozoruje tendence k transvestitismu a prvky „opačné“ genderové sebeidentifikace, od ostatních homosexuálních osob (Pfäfflin 1997). Položením dělicí linie mezi homosexualitu a transsexualitu, vyčleněním transsexuality jakožto samostatné kategorie, se sexuologie ujímá moci nad její další existencí. Historicky tím však získává nejenom moc určovat významy tohoto fenoménu, ale zároveň moc přemostit onu symbolickou rupturu, jež vzniká v důsledku narušení medicínou postulovaného vztahu kauzality mezi vlastnictvím jistých pohlavních žláz, chromozomů a hormonů na straně jedné a genderovými aspekty sebe/vnímání a jednání na straně druhé.

První pokus o chirurgickou přeměnu pohlavních znaků je uskutečněn v roce 1912 v Berlíně (Pfäfflin 1997), avšak k významnějšímu rozšíření této praxe i vypracování jistých standardizovaných diagnostických postupů dochází až během druhé poloviny 20. století. Koncem 60. let se operativní přeměny pohlaví začínají prosazovat taktéž v Československu. Definování transsexuality zůstává agendou sexuologie v podstatné míře až do dnešních dnů - odborníci/e z tohoto oboru se významně podílejí na utváření mezinárodních standardů formujících podoby managementu transsexuality a v některých zemích na tomto managementu také prŕmo participují. To platí rovněž v př́ípadě České republiky, kde sexuologie sehrává v procesu přeměny pohlaví roli zcela klíčovou. Jak se konceptualizace etiologie transsexuality v České republice vyvíjela a prostřednictvím jakých diskurzů sexuologie konceptualizuje etiologii transsexuality dnes? Jak čeští/ské sexuologové/žky transsexualitu diagnostikují?

\section{Medicína, sexuologie a genderová diference}

Základním předpokladem, na němž zde stavím, je tvrzení, že sexuologické diskurzy transsexuality nelze chápat jako něco, co nachází své uplatnění pouze v jistých výjimečných př́padech a až za dveřmi ordinací, ale že tyto diskurzy mají moc strukturovat vnímání i proživání rozličných genderových kategorií a aspektů u každé/ho z nás. Jejich uplatnění značně napomáhá i nemalá medializace problematiky transsexuality, jež bývá rámována nejčastěji právě sexuologickými výklady tohoto fenoménu.

V následujících úvahách vycházím z poststrukturalistické perspektivy poukazující na klíčovost role, kterou v kultuře sehrávají procesy reprezentace, a to zejména z Foucaultových úvah o komplexním propojení vědění a moci, o schopnosti diskurzů formovat jednání, produkovat objekty i subjekty, strukturovat lidskou subjektivitu a taktéž přístup k tělu. Ačkoli, jak tvrdí Foucault (1980, 1999), není možno stanovit, který diskurz nejvěrněji přiléhá konturám reality, nebot' pravda je ryze sociálním fenoménem, potenciálem utvářet realitu vybavuje diskurzy již samotná skutečnost, že jsou v daném historickém momentu za pravdivé považovány. Moc označit jistý diskurz za pravdivý je však v důsledku odlišných sociálních implikací různých pravd zásadním předmětem politického soupeření. Diskurz je tím, ,pro co a čím se bojuje, je mocí, které se snažíme zmocnit“ (Foucault 1994: 9). Nicméně vztah mezi 
diskurzem a mocí Foucault $(1980,1999)$ nechápe jako vztah ideologie, ale imanence, nebot' pravdivost jistého diskurzu a jeho implikace považuje za vzájemně neoddělitelné. Jakékoliv nezaujaté poznávání tedy není z této perspektivy možné - diskurzy zajištují zároveň účinky jak vědění, tak i moci.

Privilegovaný př́stup k pravdě nepřiznává Foucault (1980) ani vědě, nebot' i věda je sociální praxí odkázanou setrvávat uvnitř přediva významů, a nemůže se tedy vymanit z osidel moci a operovat jako hodnotově-neutrální nástroj poznávání. Má-li dnes věda největší moc nastolovat jisté diskurzy jakožto diskurzy pravdivé, není tomu tak v důsledku mimořádné vyspělosti jejích postupů, nýbrž v důsledku autority, kterou byla obdařena v období osvícenství. Obdobné instance umožňující jistým diskurzům jevit se jako neutrální popisy reality lze však podle Foucaulta (1980) nalézt v každé společnosti.

Z této perspektivy jsou tedy diskurzy transsexuality, které vznikají na poli sexuologie jakožto vědní disciplíny, jejíž autorita je navíc násobena př́ílastkem „exaktní“, především diskurzy navýsost mocnými a disponovanými zapisovat se prostřednictvím disciplinačních a sebedisciplinačních mechanismů do subjektů, subjektivit i těl. Možné pole jejich formativní účinnosti se dále ožrejmuje, je-li vzata $v$ úvahu poststrukturalismem tematizovaná nevymezitelnost hranice mezi př́rodním a sociálním, jejímž speciálním př́ípadem je i feminismem dříve budovaná distinkce mezi kategoriemi pohlaví a gender. Prostupují-li sociální významy již samotnou oblast „prrírodního“ a „pohlavi“, nebot' i ta je nahlédnutelná pouze skrze interpretační schémata, která se $\mathrm{v}$ dané kultuře uplatňují, ani sexuologické diskurzy, které usilují o objasnění transsexuality, nemohou vycházet pouze z „pohlavi““ a skutečností s ním spojených, ale vždy již konstruují gender.

Stejně jako je možno považovat až za důsledek sociální optiky, za diskurzivní produkt už samotnou existenci kategorie př́rodního, lze, jak ukazuje Judith Butler (2003), smýšlet také o kategorii pohlaví. Taktéž koncepce pohlavního dimorfismu, jež váže gender kauzálně k tělu a uplatňuje tak předpoklad, že nezbytnost spojení ženské a mužské pohlavní buňky pro reprodukci zakládá přirozenou odlišnost ženy a muže také v rovině ontologické, je podle Butler až součástí diskurzivního utváření genderu a výsledkem procesu jeho naturalizace. Oporou tohoto argumentu pak mohou být nejen doklady o existenci různých kultur, kde množství genderů neodpovídá námi rozlišovanému počtu typů genitálií a kde se nepředpokládá, že by genderové projevy musely nutně souviset s pohlavními atributy těla (srov. Caplan 1991, Feinberg 2000), ale i rozličné doklady pocházející z evropských kulturních dějin.

Jedním z děl ilustrujících skutečnost, že „pohlaví“, tak jak ho v našem kulturním kontextu chápeme a žijeme dnes, není univerzální lidskou přirozeností, ale až výsledkem historického procesu naturalizace, $\mathrm{v}$ němž sehrála významnou roli právě medicína, je kniha Thomase Laqueura Making sex: Body and Gender from the Greeks to Freud (1990). Laqueur (1990) zde prostřednictvím bohatého historického materiálu dokládá, že samotný předpoklad existence odlišných biologických esencí mužství a ženství, které se odrážejí ve sfére cítění, myšlení a jednání a které $\mathrm{k}$ sobě poutá vztah vzájemné komplementarity, je až záležitostí 18. století. Do konce 17. století podle něho nebylo na mužská a ženská těla pohlíženo jako na zásadně rozdílná - ženské tělo bylo vnímáno spíše jako méně vyspělá a méně dokonalá verze těla mužského, jež tak platilo za normu. Mužské a ženské reprodukční orgány neměly 
ani svá vlastní pojmenování. Jak se však Laqueur (1990) snaží ukázat, změna percepce, k níž v 18. století dochází, nenastává primárně v důsledku pokroku medicíny a prírodních věd. Ačkoli celkový epistemologický posun společnosti způsobený nástupem osvícenství a procesem sekularizace považuje za podstatný důvod rekonceptualizace těl, nastolení esencializující optiky bylo, jak tvrdí, především důsledkem nových mocenských zájmů, které 18. století přineslo - a to zejména reakcí na rozvoj veřejné sféry. Součástí soupeření o moc, které se zde odehrávalo, byla podle něj také snaha vytlačit z tohoto prostoru ženy.

Historická role medicínských diskurzů spočívala tedy podle Laqueura (1990) především $\mathrm{v}$ konečné naturalizaci genderové diference, $\mathrm{v}$ jejím symbolickém přetavení $\mathrm{v}$ „přirozenou rozdílnost pohlaví“. Různost mužského a ženského těla začala být v jejich důsledku nahlížena jako nezpochybnitelná příčina ontologické odlišnosti mužů a žen, at' už se za tuto odlišnost dosazovalo v té které době cokoliv. „Pohlavi““ se stalo mocným pozůstatkem prírody v nás, jejíž tiché instrukce nezbývá než následovat. Změnilo se ve vševyzrazující substanci, která však zůstává za každých okolností nevinná.

Jakmile byly klíče $\mathrm{k}$ genderové diferenci přisouzeny sféře prrírody, zůstaly vědám, které tuto sféru spravují, také veškeré závazky s tímto prírůstkem spojené, všechna povinnost - a ovšemže také takřka výhradní moc - „rozdílnost“ „pohlaví“ v patřičných detailech vyložit. Ve snaze tyto nároky naplnit se však lékařská věda nevyhnutně podílela a nadále podílí na naturalizujícím re-konstruování kulturní koncepce gender. V úsilí vypořádat se s nově se vyjevujícími limity stávajícího výkladu „pohlavnosti“, s limity, které zviditelnil fenomén transsexuality, pak v re-artikulování gender se stejnou nevyhnutností pokračuje také její subdisciplína - lékařská sexuologie. Skutečnost, že genderové koncepce, které sexuologie, kdykoli se snaží popsat etiologii transsexuality a stanovit způsoby, jak transsexualitu diagnostikovat, produkuje, jsou artikulacemi disciplíny, od níž se očekává privilegovaný př́stup k pravdě, ve spojení se všeobecně príijímaným předpokladem, že v případě „pohlaví“ se jedná pouze o popis jistých prrírodních zákonitostí, však vybavuje tyto sexuologické diskurzy nesmírným potenciálem stát se součástí reality. Tu nepochybně strukturuje již samotná existence transsexuality jakožto diagnostické jednotky.

\section{Od zkaženosti k vývojové poruše: Exkurz do sexuologického hledání príčin transsexuality}

Ještě v roce 1966, tedy několik desetiletí po Hirschfeldově definování transsexuality, uvádí Harry Benjamin ve své knize The Transsexual Phenomenon ([1966] 1999), že příčiny transsexuality se obecně považují za neobjasněné. Přestože v průběhu oněch desetiletí byla formulována mnohá hypotetická vysvětlení, žádné z nich nebylo v konečné fázi označeno za dostatečně průkazné. $\mathrm{K}$ širšímu konsensu ohledně prííčin transsexuality, $\mathrm{k}$ jisté stabilizaci diskurzu, dochází až koncem 60. let.

Prostřednictvím Benjaminovy knihy se v následujícím textu pokouším zmapovat rámcové body vývoje medicínského náhledu na transsexualitu ještě před stabilizací diskurzu ve světovém kontextu; diskusi o možných prŕíčnách transsexuality $\mathrm{v}$ tehdejším, $\mathrm{v}$ bádání do jisté míry izolovaném Československu pak sleduji především prostřednictvím doslovného přepisu ze sympozia $O$ soudně-lékařských otázkách transsexualismu konaného v roce 1969. 
Etiologické diskurzy analyzuji nejen s ohledem na to, jaké genderové předpoklady se v nich uplatňují, ale kladu zřetel také na obecnější mocenské zájmy, které rámovaly podoby těchto diskurzů a podmínily konečné prosazení či neprosazení se toho kterého z nich.

Perspektivou, jejímž prostřednictvím se snažím porozumět podmínkám, které mohly v lékařské obci podnítit produkci jistých diskurzů (tedy právě těchto a ne jiných), je Bergerova a Luckmannova (1999) koncepce potlačení a terapie - koncepce dvou obecných mechanismů, jejichž pomocí se instance pověřené úkolem vykládat jevy a uspořádávat tyto výklady v systematické celky (tedy např́klad věda, na niž je dnes tato agenda uvalena především) snaží zabránit možnému narušení symbolického řádu.

Mechanismus potlačení zamezuje zpochybnění nebo narušení řádu prostřednictvím devalvace alternativních definic reality. Daná, společenský rád udržující instance tak činí tím, že zbavuje osoby, jež alternativní definice formulují, obecné důvěryhodnosti ve věcech vypovídání o realitě - označuje je za méně chápavé, pomatené, nemorální nebo jinak podřadné. V poslední fázi uděluje těmto „zbloudileckým“ definicím „správný“ význam tím, že je vyloží pomocí vlastních kategorií, čímž zároveň stvrzuje platnost svých definic reality.

Zatímco potlačení operuje prostřednictvím vyloučení „nepohodlných“, mechanismus terapie je spíše snahou navrátit osoby narušující stávající symbolické struktury reality zpět do jejich područí. Za tímto účelem rozpracovává řád střežící instance jisté výklady toho, jaký „problém“ mohl vést danou osobu či osoby k odklonu od reality. Dokladem úspěšnosti terapie je pak internalizace výkladu samotnými osobami, jež původně zpochybnily ony zavedené symbolické struktury, jejich objektivní i subjektivně pocit’ovaný návrat k „normalitě“.

Mechanismy potlačení a terapie nahlížím v případě medicínsko-sexuologického pátrání po př́činách transsexuality jako dvě formy obecnějšího politického pozadí spolupodílejícího se na konkrétních podobách jednotlivých diskurzů, jako podloží strukturující debatu v rámci této vědecké obce do dvou pomyslných vývojových fází.

\section{I. Transsexualita potlačitelskou optikou: Ztracená soudnost, nebo nalezená lest?}

Ideální dokumentaci počátků medicínských a sexuologických diskusí o možných příčinách transsexuality v tehdejším Československu představuje přepis příspěvků ze sympozia O soudně-lékařských otázkách transsexualismu (Dobrotka 1969, Hynie 1969, Neoral 1969, Rozmarič 1969, Widermannová 1969, Diskuse 1969). Tak závažné nerespektování kontur symbolického řádu, jakým popření kauzálně formulovaného vztahu mezi pohlavními znaky těla a genderovou sebeidentifikací bezpochyby je, si zde vynutilo použití veškerých potlačujících metod, o nichž se Berger s Luckmannem (1999) zmiňují. Lze se tedy domnívat, že to bylo právě vnímání transsexuality jako něčeho významně narušujícího symbolický řád, co strukturovalo první diskurzy usilující o postižení možné příčiny transsexuality.

\section{Transsexualita jako psychóza}

Za možný zdroj touhy po chirurgické přeměně byla v souladu s potlačitelským viděním označena „utkvělá myšlenka“ (Rozmarič 1969) či přímo „trvalá patologická změna osobnosti“ (Dobrotka 1969). Diskutovanými důsledky obecného prijietí této interpretace „nesouladu“ mezi tělesnými atributy a genderovou identitou v lékařsko-sexuologické obci byly nejen 
zamítnutí možnosti chirurgické přeměny pohlaví, ale také zbavení transsexuálů/ek způsobilosti k právním úkonům.

\title{
Transsexualita jako forma narcistního infantilismu
}

Konceptualizace „opačné“ genderové sebeidentifikace jako důsledku infantilismu je založena na předpokladu pozměněné osobnostní struktury, jež se vyznačuje sníženým intelektem zapříčiňujícím nedostatečné porozumění realitě a neschopnost jednat v souladu s jejími pravidly. Předpokládalo se, že v důsledku této „neschopnosti““ se dané osoby snaží všemožně napodobovat své okolí, k čemuž si čas od času zvolí „nepatřičný““ vzor (Widermannová 1969):

Tento talent ke kopírování, $\mathrm{k}$ infantilní imitaci by snad mohl připadnout v úvahu jako klíč - nebo skromněji jako jeden z klíčů - k záhadě transsexuelního fenoménu. Celý jev výrazně připomíná dětinský sklon chtíti to, co se dá odkoukat u souseda, bez ohledu na adekvátnost předmětu tohoto žárliveckého obdivu. [...] Celoživotní pošilhávání infantilních osobností po druhých vzorech je důsledkem jejich usilovně maskované vnitřní nesamostatnosti a bezradnosti, jakož i chabosti jejich krátkozraké, katathymně mezerovité a hlavně skotomizované logiky. (Widermannová 1969)

Tón záště, jenž není u potlačitelských diskurzů obecně ničím výjimečným, vychází $\mathrm{v}$ tomto případě z morálního aspektu, přítomného ve spojení transsexuality s infantilismem. Transsexualita totiž není nahlížena jen jako pouhá politováníhodná neschopnost orientovat se $\mathrm{v}$ realitě, ale také jako netečnost ke společenským zřetelům, v níž si daná osoba přímo libuje. Předpokládalo se tedy, že transsexualita může vycházet z narcistických pohnutek, jež se s infantilismem pojí, z touhy vyčnívat a jevit se někým zvláštním. Jak ve svém komentáři k (nejen) transsexuály/kami často užívané konceptualizaci transsexuality jakožto „omylu přírody“ tvrdí Libuše Widermannová:

\begin{abstract}
Alibismus tohoto transsexuálního „axiomu“ o omylu přírody je snad pro infantilní mentalitu nepř́iznačnější. „Já ne - to jiný“ zůstává hlavním zřetelem, který si infantil nepřestává nikdy hlídat při svém neustálém strachu před odpovědností na jedné straně a bytostným sklonem k pošetilým bláhovostem na straně druhé. Odkaz na nějakou vis maior je přitom obzvláště oblíbenou inspirací. Diktuje to i infantilní narcismus, kdy se takto subjekt ocitá ve výlučném postavení. Hoví mu jevit se někým, koho sama př́roda vybrala pro svá tajemná kouzla. (Widermannová 1969)
\end{abstract}

Drobné zmínky o narcismu jako jednom z možných kořenů touhy po transsexuální přeměně, které by mohly poukazovat na obecnější přijetí tohoto - původně spíše psychiatrického - diskurzu v rámci české sexuologické obce, se pak objevují také v novější literatuře (srov. Hynie 1980a; Molčan, Bardoš a kol. 1989).

\section{Transsexualita jako prostředek k ukájení „nemorálni" sexuální touhy}

My nevíme, co je ta jednotka ještě přesně, ale my víme bezpečně, že tito ubozí trpící transsexuálové se ukazují na Reeperbahnu, přeoperovaní v Hamburku, ve striptýzech. [...] Že je tam řada vysloveně morálně nezdravých lidí - moral insanity. Že jsou to lidé, kteří skutečně se slušnou společností mnohdy nemají co do činění. (Neoral 1969) 
Vyvolává-li překročení norem vždy jisté konotace nemorálního, byl v př́ípadě transsexuality pro její zahrnutí těmito významy „důvod“ hned dvojí. Vedle samotné „opačné“ genderové sebeidentifikace napomohla označení transsexuality jako něčeho nemorálního také skutečnost překročení norem sexuality, nebot' většinu osob usilujících o chirurgickou přeměnu lze zároveň označit za homosexuály/lesby. $\mathrm{V}$ důsledku kulturního předpokladu, že sexualita je nejdůvěryhodnějším klíčem k našemu nitru, byla „opačná“ genderová sebeidentifikace vyložena jako něco, co z této „odchylné“ sexuality patrně nějak vychází. Obtěžkanost homosexuality nejen nemorálními, ale oproti heterosexualitě také zvýšeně sexuálními konotacemi vyústila $\mathrm{v}$ interpretaci touhy po chirurgické přeměně jako prostředku, jímž si homosexuálové/lesby chtějí zaručit snadnější přístup k „ukájení“ svých „nemorálních“ sexuálních tužeb. Transsexualita byla tedy konceptualizována jako něco souvisejícího právě a především se sexem, sebeidentifikační nebo jiné možné aspekty byly naopak zcela upozaděny.

Z morálně-etického hlediska je tzv. operativní přeměna pohlaví nemožná, nebot' výsledkem operace se pohlaví nemění, dopomáhá jen k realisaci homosexuálních (tribadických) praktik podle halucinací transsexuálů. [...] Podle dosavadních sexuologických poznatků modi exercendi homosexuálního ukájení pohlavního pudu u transsexuálů nevyžaduje nezbytně plastiku pseudokopulačních orgánů za cenu zkomolující operace. (Rozmarič 1969)

Tentýž diskurz se však objevuje také v novější sexuologické literatuře:

V některých případech může být oblékání šatů druhého pohlaví pouhým trikem, aby se dotyčná osoba dostala snadno mezi osoby druhého pohlaví a měla lepší možnost ukojování svých sexuálních choutek [...] Někdy může být uvědomění takové tendence do značné míry zastřeno. Dotyční lidé dělávají dojem lidí korektních, nebo i svatoušků. Nahodilá zkušenost může být přes zdánlivé vnitřní boje podnětem $\mathrm{k}$ dalšímu rozvinutí touhy po přestrojování, při němž by sexuální žádostivost byla snáze ukojována. Maskování této žádostivosti bývá někdy i před vlastní osobou takového rázu, že z toho bývá pobouření, když dotyčnému poukážeme na to, čemu jeho záliba $\mathrm{v}$ přestrojování slouží. [...] Přirozeně v prvé řadě psychopati a neurotici jsou schopni rozvinout takové triky, ne dosti subjektivně chápané ve své podstatě. (Hynie 1980a: 72)

Narušení struktur symbolického řádu zabraňuje sexuologie $\mathrm{v}$ tomto př́ípadě vyložením alternativních definic reality prostřednictvím vlastního jazyka, čímž dodává touze po chirurgické přeměně tělesných znaků její „objektivní“ význam, nalézá její „,skrytý motiv“, jímž má být snaha usnadnit si „ukájení“ sexuální touhy. Potlačení je završeno zbavením osob formulujících alternativní definice reality důvěryhodnosti ve věcech vypovídání o realitě.

\section{Transsexualita jako prostředek homosexuálů a leseb k dosažení „normality"/ heterosexuality}

Podobně jako u předchozího diskurzu se i zde očekává, že požadování chirurgické přeměny pohlavních znaků může být kalkulovaným prostředkem k dosažení určitého „zisku“. Ten je však v tomto prrípadě očištěn od sexuálních konotací. Předpokládá se, že přání podstoupit danou operaci motivuje především touha po jistém společenském „Zneviditelněni““ - snaha zmírnit dopady zakoušené stigmatizace sebe jako lesby/homosexuála, př́padně sebe jako „prrílišs“ maskulinně působící ženy-lesby nebo „přílišs“ feminního muže-homosexuála: 
Je nutno delším vyšetřováním si zjistit, oč vlastně jde. Protože někdy může být žádost o předělání výsledkem okamžitého rozmaru virilní ženy, kterou napadne, že by měla tak životní situaci mezi lidmi usnadněnou. (Hynie 1969)

Reprodukci této úvahy lze nalézt také v současné literatuře:

V některých případech by se o změnu pohlaví mohli snažit homosexuálně orientovaní lidé, kteří by se domnívali, že tímto způsobem vyřeší svou obavu z nepřijetí společností, případně se domohou většího společenského uznání jejich vztahu. (Procházka 2002: 39)

Diskurz interpretující chirurgickou přeměnu jako možný prostředek dosažení heterosexuality poukazuje na klíčovou roli heterosexuality v sexuologickém pojetí normality - homosexualita je vnímána jako natolik zásadní překážka normality, že se stává myslitelným, že právě samotná touha se jí „zbavit“ může motivat celé prání podstoupit chirurgickou přeměnu pohlaví.

Akcentaci homosexuality a popření jiných aspektů transsexuality lze považovat také za způsob, jímž operuje mechanismus potlačení. To se neodehrává prostřednictvím tak důrazného symbolického umlčení, jaké nacházíme v př́ípadě předchozích diskurzů, ale spočívá zejména v neuznání definice situace jakožto situace transsexuality, v jejím přeložení do vlastních pojmů - v klasifikaci touhy po přeměně jako touhy vyřešit problém s homosexualitou. Implikací tohoto diskurzu je, stejně jako $\mathrm{v}$ předchozích př́padech, odepření chirurgické přeměny.

$* * *$

Vedle potlačitelské optiky se však již v rámci sympozia $O$ soudně-lékařských otázkách transsexualismu objevují také prvky optiky terapeutické - diskurzy, které přijímají definici situace, s níž transsexuálové/ky do lékařských ordinací přicházejí, jako reálnou a klasifikují transsexualitu jako medicínský problém, jenž si žádá odpovídající řešení. Vzhledem k tomu, že primárním cílem konání sympozia bylo nalézt optimální způsob, jak v př́ípadech transsexuality postupovat, bylo také nevyhnutelné dospět $\mathrm{k}$ jistému konsensu ohledně jejích významů. Jelikož zúčastnění/é i přes počáteční převahu potlačitelských stanovisek projevili dostatečnou vůli dané osoby „nevyloučit“ (opakovaně bylo zmiňováno značné utrpení transsexuálů/ ek, jejich sklony k sebepoškozování a sebevraždám, a poukazováno bylo také na relativní úspěšnost chirurgických řešení ve srovnání s metodami nechirurgickými), bylo nakonec rozhodnuto ve prospěch institucionalizace operativních přeměn pohlaví a prosazena byla optika terapeutická. Při hledání př́íciny transsexuality se sexuologie začala obracet k substanci.

\section{II. Transsexualita terapeutickou optikou: Hledání místa poruchy}

Jakmile se začalo na transsexualitu pohlížet optikou terapeutickou, jako na reálný stav, který si vyžaduje léčbu, pole možných etiologických diskurzů bylo patrně již předurčeno oborovým zakotvením vědních disciplín, které se úkolu objasnit transsexualitu zmocnily. Mělo-li být vysvětlení transsexuality nalezeno právě na poli medicíny a sexuologie, prostory určené $\mathrm{k}$ propátrání byly vymezeny mantinely těla. Začalo se tedy s prověřováním pilírư, na nichž je vystavěna medicínská koncepce pohlaví - pohlavních chromozomů nesoucích geny a pohlavních hormonů. 


\section{Transsexualita jako chromozomální, genetická nebo hormonální porucha}

O prvních výzkumech, které se pokoušely nalézt prŕíčinu transsexuality v odlišných tělesných parametrech transsexuálů/ek, padla na sympoziu O soudně-lékařských otázkách transsexualismu spíše pouze zmínka (srov. Rozmarič 1969). Detailněji o nich však pojednává Benjamin ([1966] 1999) ve své analýze „transsexuálního fenoménu“. Jednou z testovaných hypotéz podle něho bylo, že by transsexualita mohla být důsledkem abnormální konstelace pohlavních chromozomů. Žádná anomálie v této oblasti však prokázána nebyla.

V další fázi se, jak Benjamin ([1966] 1999) uvádí, uvažovalo o zakotvení genderové identity v úrovni genů, v důsledku čehož se transsexualita jevila jako porucha zpo̊sobená přemístěním ,genu pro pocit mužství/ženství“, narušením genové struktury očekávaně zakládající genderovou diferenci:

Lze předpokládat, že pohlavní chromozomy nesou gen, který souvisí s identifikací a pocitem mužství nebo ženství a že se tento pohlavní gen váže k chromozomu Y u mužů a k jednomu (nebo oběma) chromozomům X u žen. Pokud se však naruší tato vazba, potom se gen související s pohlavní identifikací, který se normálně váže $\mathrm{k}$ jinému genu podmiňujícímu pohlavní odlišnost, může přemístit a spojit s genem pro opačné pohlaví, což může vyústit v transvestitismus. ${ }^{2}$ (Melicow a Uson in Benjamin [1966] 1999)

Ani důkazy o podmíněnosti transsexuality genetickými dispozicemi však nalezeny nebyly, pročež se pozornost obrátila spíše k možným hormonálním diferencím. Začalo se prověřovat, zda transsexualitu nemohou způsobovat odchylky v produkci pohlavních hormonů, př́padně anatomické zvláštnosti žláz, které hormony produkují. Žádné rozdíly mezi transsexuály/kami a ostatní populací však nebyly prokázány (Benjamin [1966] 1999).

\section{Transsexualita dnes - transsexualita jako důsledek poruchy vývoje mozku}

Také v př́padě tohoto diskurzu - který byl zároveň oním diskurzem, jenž byl nakonec prosazen na zmiňovaném sympoziu - se vycházelo z předpokladu, že transsexualita je zapříčiněna odchylným hormonálním působením; avšak nyní se pozornost obrátila již k fázi prenatálního vývoje. Tento obrat byl iniciován zjištěním, že uživání různých hormonálních př́pravků během těhotenství může deformovat genitálie plodu. Na jeho základě Benjamin ([1966] 1999) postuloval možnou analogii i u procesů způsobujících transsexualitu - transsexualita se mu jevila být důsledkem bud' prŕilišného zaplavení mozku mužského plodu estrogenem nebo mozku ženského plodu androgeny.

Konečnou podobu dnes všeobecně přijímanému vysvětlení transsexuality však vtiskl až objev W. Younga, R. W. Goye a C. H. Phoenixe z přelomu 50. a 60. let (Benjamin [1966] 1999; Zvěřina 1994). Tito vědci vysledovali, že samice morčat, které byly v prenatálním stádiu vystaveny působení testosteronu, měly po porodu maskulinizované genitálie a ani přes pozdější podání estrogenů nebyly v budoucím životě schopny sexuálního chování typického pro samice. Obdobný efekt s estrogeny se však neprokázal. Jejich pozorování byla

Jak však tvrdí Benjamin ([1966] 1999), autoři hovoří o „transvestitismu“ v důsledku nejednotnosti pojmů, přičemž mají na mysli „transsexualitu“. 
později potvrzena i na jiných živočišných druzích - u psů, myší, ovcí, opic a některých ptáků (Zvěřina 1994).

Především v důsledku těchto zjištění se zformovala představa jistého pohlavně specifického mozkového centra diferencovaného prenatálním působením androgenů - tzv. centra pohlavní identity -, které muže a ženy vybavuje odlišnými dispozicemi: je-li vystaveno působení androgenů, strukturuje se „mužským“ způsobem, nedojde-li však k tomuto působení, zůstává navždy strukturováno „žensky“. Základem sexuologické koncepce transsexuality se stal předpoklad, že toto centrum se může za určitých podmínek vyvíjet „opačně“ vůči ostatním pohlavním komponentám těla, tedy že androgeny mohou za jistých okolností strukturovat rovněž mozek jinak normálně se vyvíjejícího ženského plodu nebo naopak nestrukturovat mozek po jiných stránkách zcela normálně se vyvíjejícího plodu mužského. Jak mechanismus tohoto „opačného“ „naprogramování“ mozku a jeho hypotetické příčiny shrnují Fifková a Weiss:

Organizace těchto oblastí [mozku] je závislá na hladině pohlavních hormonů a neurotransmiterů v kritických vývojových obdobích během nitroděložního života. Změny hladin specifických pohlavních hormonů vedou k trvalým strukturálním nebo biochemickým změnám těch oblastí mozku, které jsou spojeny s celoživotními variacemi chování v pohlavní roli nebo se sexuální orientací. Za mužskou organizaci sexuálního mozku je zodpovědná hladina androgenů. U ženského plodu může dojít k nadprodukci androgenů nadledvinkami a mozek tedy může být organizován jako mužský. Naopak varlata mužského plodu mohou produkovat výrazně nižší množství androgenu a mozek plodu může být organizován jako ženský. Nadprodukce, resp. nižší produkce může být způsobena nedostatkem enzymů a podpořena mateřským stresem v kritických obdobích prenatálního vývoje. (Fifková a Weiss 2002: 24)

Formoval tuto fázi vývoje sexuologického diskurzu požadavek materiálně ukotvit předpokládanou „duši“? Jisté je, že přesun pozornosti k mozku nastává poté, co byly vyčerpány veškeré možnosti prokázat odlišnost žadatelů/ek o přeměnu od „,normálni'“ populace v některém z tělesných parametrů, na jejichž základě se určuje pohlaví. Bylo-li však z pozic věd, které byly pověřeny úkolem transsexualitu vysvětlit, jako substancionální nahlíženo již gender, nemohla se ze substancionální logiky vymanit, měl-li být uskutečněn terapeutický záměr, ani konceptualizace transsexuality. Terapeutické úsilí vyložit transsexualitu jako fenomén neproblematicky přiléhající ke stávajícím symbolickým strukturám, úsilí dodat jí definici, která by umožnila osobám, jež se prostřednictvím „opačné“ genderové sebeidentifikace vymanily z dosahu symbolických struktur, návrat do jejich př́střeší, se tedy v tomto prípadě realizovalo prostřednictvím snahy lokalizovat kořeny stále objektivně nezachytitelné transsexuality v substanci zodpovídající za veškerou oblast subjektivního - v mozku.

Postulovanému „centru pohlavní identity“ byla přiřknuta schopnost generovat veškeré vlastnosti, jejichž genderovanost byla zviditelněna problémem „opačné“ genderové identifikace - stalo se prostorem nejrůznějších kulturních projekcí. „Pohlavní identita vyjadřuje subjektivně vnímaný pocit sounáležitosti či naopak rozporu s vlastním tělem, s jeho primárními a sekundárními pohlavními znaky, i se sociální rolí přisuzovanou danému pohlaví. Má kognitivní i emocionální komponentu, odráží se v myšlení, cítění i chování jedince včetně jeho profese, zájmů, společenských vztahů“ (Procházka a Weiss 2002: 13). Skutečnost, že tyto nemalé výkladové ambice vložené do koncepce centra pohlavní identity byly odvozeny 
především od pozorovaných změn sexuálního chování u morčat, psů, myší, opic a některých ptáků, tedy skutečnost, že tato analogie skýtá četná úskalí, byla pro sexuologii vyvážena explikačními „„yrínosy“ nově nalezeného nástroje. „Je zcela pochopitelné, že u lidí nemůžeme provést kontrolované experimenty s prenatální hormonální manipulací. Přesto lze oprávněně usuzovat na to, že pokud se prenatální organizace mozku pod vlivem androgenů uplatňuje u zvířat, musí v nějaké formě existovat též u lidí“ (Zvěřina 1994: 89).

„Centrum pohlavní identity“ opakovalo a rozššrílo neduhy všech předchozích substancí, jejichž pomocí mělo být vyloženo gender. Zhmotnilo předpoklad univerzálního mužství a ženství vyvázaného z kulturních a historických kontextů a nezávislého na etnicitě, sociálním postavení či sexualitě konkrétních mužů a žen a vystavělo mužství a ženství jako vzájemně protichůdné a neprostupné sféry. Nejen, že byla „centru pohlavní identity“ přiznána privilegovanost nad kulturou, upozaděny byly také substance, které obvykle rámují sexuologický výklad genderové diference - genetická výbava a pohlavní hormony. Právě tímto nadsazením míry vlivu „centra pohlavní identity“ bylo dosaženo terapeutického účinku. Opětovně byl potvrzen kulturní předpoklad, že gender je kauzálním důsledkem pohlavnosti těla, a zdánlivě se pouze upřesnil konkrétní činitel, jenž se na spatřované diferenci podílí největší měrou. Platnost dříve ustavených definic reality tak zůstala zachována, upozadění v sexuologii tradičně zvažovaných původců genderové diference však zároveň umožnilo vysvětlit skutečnost, že přináležitost k druhému ,pohlavi““ je pocit’ována - i přes normální chromozomální konstelaci a hormonální produkci - jako relativně jednoznačná. „Transsexuální lidé jsou od narození mateni - mají nějaké tělo, nějaký genitál, nějaké jméno a rodné číslo, nějakou výchovu, a naprosto opačnou rodovou identitu, která nakonec všechno přebije“ (Fifková 2004). Definitivně zpřetrhána byla dř́ivější spojení transsexuality s nemorálním, vinou nebo jinou formou zodpovědnosti - transsexualita byla postavena mimo sféru možného ovlivnění, stala se vrozenou, a tedy nezměnitelnou poruchou. Jako „porucha pohlavní identity“ byla později zařazena do Mezinárodni klasifikace nemocí, kde pod kódem F 64.0 - v kategorii „Nemoci duševní a poruchy chování“ - figuruje dodnes.

$* * *$

Jakmile se transsexualita zdála být uspokojivě vyložena, začala sexuologie s přeuspořádáváním symbolického rádu - po substancionalizaci transsexuality začalo být na tento fenomén pohlíženo jako na něco existujícího vždy a všude, něco dříve pouze nepozorovaného a „neléčeného“. Stejně jako v prrípadě uvažování o „pohlaví“ se sexuologické tř́ídění symbolického řádu ani $\mathrm{v}$ př́padě transsexuality nevyhnulo ahistorickým a etnocentrickým projekcím. „Snad nejznámějším př́íladem pravděpodobného transsexuálního chování ve středověku je legendární Johanka z Arcu“ (Procházka a Weiss 2002: 15). „Transsexualita byla popisována i u nativních Američanů“ (Procházka a Weiss 2002: 16). Výsledky mezinárodních srovnání, které dokládají značnou odlišnost počtů žadatelů/ek o chirurgickou přeměnu v různých zemích, byly v důsledku uplatnění předpokladu relativně stabilní míry výskytu transsexuality v populaci interpretovány jakožto doklady o rozdílných počtech osob, které se v odlišných kulturních podmínkách jednotlivých zemí odhodlaly k transsexualitě přihlásit (srov. Fifková 2002b; Procházka a Weiss 2002). 


\section{K sexuologické konstrukci heterosexuality u transsexuálů/ek}

V důsledku přijetí předpokladu, že lidé žádající o transsexuální přeměnu vzhledem k ,opačně“ zformovanému ,centru pohlavní identity“ jsou již ve skutečnosti „uvnitř゙“ „pohlavím“, jehož tělesné znaky chtějí získat, se změnila také sexuologická percepce jejich sexuální „orientace“. Bylo-li před ustavením diskurzu interpretujícího transsexualitu jako poruchu mozku možno označit většinu osob usilujících o přeměnu pohlaví za homosexuály/lesby, s rekonceptualizací jejich ,,pohlaví“ byla i jejich sexualita překlasifikována jako heterosexualita. Přiznání statusu „normality“ se tedy odrazilo i v očekávání „náležitého“ spojení mezi „pohlavím“ a podobou sexuální touhy. Postulovalo se, že podíl homosexuálních transsexuálů/ek přibližně kopíruje podíl homosexuálů/leseb v celkové populaci (Weiss, Fifková a Procházka 2002b; Skoblík 2006).

Stálo-li však původně v základu teorie o vlivu androgenů na organizaci lidského mozku zjištění Younga, Goye a Phoenixe, že prenatální podávání androgenů způsobuje u samic některých zvírat změny ve vzorcích jejich sexuálního chování (Benjamin [1966] 1999; Zvěřina 1994), také po rozhodnutí aplikovat tyto poznatky na člověka se zřjejmě muselo - před jejich vztažením k genderové identitě - v první řadě uvažovat o možných dopadech androgenů na lidské sexuální chování. Avšak vzhledem k tomu, že sexuologie prostřednictvím uvedeného mechanismu skutečně interpretuje rovněž homosexualitu (srov. Fifková a Weiss 2002; Zvěřina 1994), jak pak vysvětluje fakt, že většina transsexuálů/ek není v důsledku hormonálního „,přeladění“ mozku zároveň homosexuální, tedy že není přitahována ,pohlavím“, jehož tělesné znaky chce získat?

Ve snaze objasnit a zároveň substancionálně ukotvit prostřednictvím objeveného mechanismu každou z variant - heterosexuální transsexualitu, homosexualitu i homosexuální transsexualitu - byla formulována hypotéza dvou oddělených center. „Centrum pro sexuální identifikaci a orientaci nebude zřejmě totožné, protože odchylky obou zmíněných kvalit se mohou vyskytovat do značné míry na sobě nezávisle“ (Zvěřina 1994: 36). Každé z těchto center se formuje, předpokládá se, v jiné fázi prenatálního vývoje. „Je vysoce pravděpodobné, že diferenciace centra pro sexuální identifikaci probíhá poněkud dříve než stejný proces centra pro sexuální orientaci. Tak lze vysvětlit možnost rozdílného ,naprogramování těchto center" (Zvěřina 1994: 91). Sexuologií naturalizovaná norma heterosexuality byla tedy vztažena také vůči transsexuálům/kám. I přes vyložení stavů, které této normě neodpovídají, čili přes biologickou interpretaci homosexuální transsexuality, však nepřestává př́ípadná homosexualita transsexuálů/ek budit zvýšenou diagnostickou pozornost, nebot' zasažení obou předpokládaných mozkových center, které má homosexuální transsexualitu způsobovat, je percipováno jako nepravděpodobné.

\section{Pravidla diagnózy}

Je-li sexuologií transsexualita definována jako důsledek pohlavně-opačné strukturace mozku a zůstává-li tedy něčím objektivně neuchopitelným, jaké příznaky mužství či ženství jsou uznány za relevantní důkazy pro stanovení diagnózy F 64.0? Jakým způsobem se sexuologické předpoklady o genderu a sexualitě, na nichž je tato etiologická koncepce transsexuality vystavěna, promítají do pravidel standardizovaného diagnostického postupu? Jak se 
odrážejí v kritériích, která jsou pro potvrzení či vyvrácení diagnózy transsexuality určující, a jak jsou pro diagnostické účely dále rozpracovávány?

Základní kroky diagnostického postupu - tak jak je, dle dostupných pramenů, uplatňován v České republice - se řídí souborem klinických doporučení Standardy péče pro poruchy pohlavní identity (2002), které vydávaná Světová profesní asociace pro zdraví transgender osob (WPATH). Primárním diagnostickým nástrojem je zde nestrukturovaný rozhovor. Pozornost se soustřed'uje především na tři roviny: neměnnost stavu, „typický“ transsexuální vývoj a odlišení transsexuality od jiných „onemocnění“ a stavů (Procházka 2002). Zejména těmto rovinám bude tedy věnována i následující část analýzy.

\section{I. Rétorika substance}

Jestliže byly v dobách, kdy se ještě o transsexualitě uvažovalo jako o formě obecnější tělesné intersexuality, prověřovány u žadatelů/ek o chirurgickou přeměnu nejrůznější tělesné parametry, z nichž, jak se očekávalo, měla pozměněná genderová sebeidentifikace vycházet, dochází se všeobecným přijetím vysvětlení transsexuality jako vývojové poruchy mozku k nahrazení požadavku tělesné odlišnosti požadavkem alespoň nepřímého důkazu vlastnictví dané zpohlavňující substance - požadavkem rétoriky, která líčí pocitovaný stav jako neměnný. ${ }^{3}$

Neměnnost „opačné“ genderové sebeidentifikace je vedle samotné touhy po chirurgické přeměně a podmínky vyloučení psychotických příčin jedním z hlavních kritérií, o něž se má podle Standardỉ péče pro poruchy pohlavní identity (2002) diagnostika transsexuality opírat. Z tohoto důvodu je diagnostika založena na opakovaných rozhovorech a dlouhodobějším pozorování (Marešová a Weiss 1998). Spolu s životní setrvalostí si uznání diagnózy transsexuality vyžaduje také ztotožnění transsexuálů/ek s jistým konkrétním diskurzem - diskurzem pojímajícím transsexualitu jako „omyl př́rody“. Klinická definice transsexuality totiž

Úsilí prokázat tělesnou odlišnost transsexuálů/ek od „normální“ populace však neustává ani po přijetí diskurzu transsexuality jako poruchy mozku a předpoklad, že tato odlišnost existuje - byt' bylo po vyloučení chromozomálních a hormonálních variant stále méně jasné, o jakou odlišnost by se mělo jednat - zcela neopustil ani diagnostickou praxi. Ještě v roce 1980 Hynie píše: „Jestliže se setkáváme s transvestitismem u lidí, u nichž je pro to pramálo tělesných dispozic, není to zpravidla s jejich psychismem zcela $\mathrm{v}$ pořádku, alespoň najdeme něco ve smyslu psychopatických nebo psychoneurotických dispozic“ (Hynie 1980a: 73). Pozůstatky tohoto způsobu uvažování, jakkoli zřídkavé, se však promítají i do současných diagnostických kritérií. Jak uvádí sexuoložka Hajnová: „To je skládání mozaiky, kdy máte rozhozené střípky a vy sbíráte vzorec, který vám diagnózu bud' přibližíi, nebo zpochybní. Samozřejmě nacházíme klienty, u nichž naprosto ode dveří víte, že je to tato diagnóza. Když vidíte, že jedinec má široká ramena, úzké boky, trojúhelník typický pro muže je tam vytvořen. A přestože jsou tam ženská prsa a genitál, nastavení nohou a rukou odpovídá mužskému. A zase opačně najdete muže, který má krásnou figuru ženského tvaru přesýpacích hodin, vše je to křehké a jemné. To je jeden ze znaků, které svědčí zase pro ženské pohlaví. A takhle se dá pokračovat" (Klausová 2001). 
zahrnuje „víru, že dotyčný je př́slušníkem opačného pohlavi““ (Weiss, Fifková a Procházka 2002: 27). K implicitním diagnostickým kritérím tedy patří povinnost žadatelů/ek o chirurgickou přeměnu ztělesňovat sexuologií uplatňované esencialistické genderové koncepce. Prezentují-li se transsexuálové/ky prostřednictvím jiných diskurzů, představuje tato odlišná sebeprezentace - jakkoli by byl život $\mathrm{v}$ daném pohlavním těle popisován jako nesnesitelný překážku pro vydání souhlasu k operaci.

Diagnostický požadavek neměnné genderové identity i požadavek, aby se transsexuál/ka definoval/a jako člověk, jehož „duše“ je v důsledku pochybení prrírody uvězněna v pohlavněopačném těle, se zakládá, podobně jako jiné esencialistické koncepce genderu a transsexuality, na modelu sociálního světa jako něčeho odvozovaného z biologické podstaty člověka. Dle této, nejen $\mathrm{v}$ př́rodních vědách etablované představy, jež v průběhu historie vystřídala ideu božského řádu, jsou myšlenky a jednání odrazem tělesně zakotvených vrozených charakteristik, a tedy i zpohlavňujících pilířu těla. Pocity v rámci tohoto modelu zprostředkovávají ryze osobní reflexi vrozeného a jsou vnímány jako něco předcházejícího myšlenkám. Člověk je uzavřenou jednotkou, na jejímž povrchu se teprve odehrává sociální.

Tuto logiku - ve vztahu k sociální změně - ilustruje tvrzení Procházky a Weisse: „S překonáváním omezení tradiční patriarchální společnosti se ve vyspělých zemích zmírňují kulturně specifické rozdíly mezi pohlavími, nicméně zůstávají zachovány projevy biologické a psychologické odlišnosti“ (Procházka a Weiss 2002: 14). Co konkrétně však postulovanou přetrvávající odlišnost konstituuje? Neboli: Existuje skutečně něco, jak tuto otázku formuluje Butler (2003), co mají všechny ženy bez ohledu na kulturní př́slušnost, sociální postavení, věk, sexuální preference a nespočetné jiné charakteristiky společné (přičemž stejně je třeba se ptát i v případě muži̊)? Doklady o kulturních rozdílech mezi „pohlavími“ totiž nelze chápat jako prosté doklady odlišného vnějšího uspořádání, jak předpokládají Procházka s Weissem (2002), nebot' odlišné genderové koncepce a normy, jež stojí v základu této různosti kulturních uspořádání, mají moc promítat se za kulturně vytvořenou hranici mezi sociálním a psychologickým - mají moc formovat sebe/percepci, emoce, jednání i př́stup k tělu, a tedy moc vytvářet rozdílnost i v těch „nejniternějších“ rovinách.

Podobně jako se tedy nelze cítit být mužem nebo ženou oproštěně od daného symbolického řádu, který těmto pojmům dává jejich význam, nelze ani o těle uvažovat jako o něčem, co by své/mu nositeli/nositelce mohlo dát jistými způsoby vytušit svou biologickou přirozenost, pravdivé pohlaví, skrývající se za slupkou pohlavně-opačného těla. Obojí je prostředkováno a konstituováno dostupnými kulturními zdroji. Jak tvrdí Foucault (2003), pravda sebepoznání je pravdou diskurzu. Hledání „skrytých“ pravd o sobě je inkorporovaným kulturním imperativem a zároveň také mechanismem, jehož prostřednictvím se podrobujeme diskurzům a vytváŕíme sebe sama, svazujeme se s jistou identitou.

Avšak ani skutečnost, že transsexualita je kulturním faktem či účinkem diskurzů, nezlehčuje její subjektivní naléhavost. Neznamená to, že by vycházela z osobní vůle nebo byla vưlí ovlivnitelná či nutně psychoterapií odstranitelná, jak se domnívají sexuologové/žky (srov. Fifková 2001, Klausová 2001, Fifková a Weiss 2002). Ačkoli diskurzivně konstituovaná subjektivita je subjektivitou inherentně nestabilní, myšlením a verbálními projevy neustále rekonstituovanou, neubírají jí tyto rysy na hloubce a reálnosti. V di̊sledku schopnosti diskurzu strukturovat nevědomé obsahy a emoce, vázat nevědomou energii, si vytváŕíme 
v průběhu naší individuální historie, jež je zároveň historií podrobování se jistým diskurzům, pocitově-myšlenkové vzorce a vzorce jednání, které mohou být relativně setrvalé (Weedon 1987). Transsexualita tudíž může být pocitována jako neměnná, aniž by se tato neměnnost musela zakládat na substanci. Diagnostické úsilí potvrdit či vyvrátit na základě výpovědí transsexuálů/ek poruchu postulovaného mozkového centra představuje z tohoto úhlu pohledu stanovování hranice uvnitř kontinua různě silné a různě trvalé identifikace s mužstvím nebo ženstvím.

\section{II. Mít „správný“ príiběh}

\section{„Zdravé" a „nezdravé" dětství}

Požadavek trvalosti pocit’ované odlišnosti, která má doložit přítomnost „opačně“ vyvinutého „centra pohlavní identity“, je součástí veškerých diagnostických kritérií. Očekává se tedy také, že jeho prrítomnost bude potvrzena celoživotní preferencí takových aktivit, které jsou pro dané „pohlaví“ „patřičné“. Pro klíčové důkazy se sexuologie obrací k období dětství jako životní fázi ještě neposkvrněné, jak předpokládá, působením kultury, i životní fázi ještě nepoznamenané př́ípadným úmyslem změnit si pohlavní znaky z nějakého jiného popudu, než je „skutečná“ transsexualita.

Jak uvádí Weiss, Fifková a Procházka (2002), jedním z vodítek uplatňovaných v rámci „anamnestické explorace“ je preference „pohlavně-patřičných“ hraček a her v předškolním věku. Konkrétní př́klady takových hraček a her jmenují Procházka s Weissem: „Mezi sexuálně odlišné záliby patř́i u chlapců bojové sporty (fotbal, hokej, zápas) a technické zájmy (auta, motory, elektrotechnika). K dívkám patří spíše panenky, hry na domácnost, domácí práce, oblékání, ze sportů spíše neagresivní hry“ (Procházka a Weiss 2002: 14). Výběr uvedených hraček a her, jakkoli kulturně a historicky specifické atributy maskulinity a femininity reprezentuje, je sexuologií percipován jako důsledek v mozku zakódovaných inherentně mužských nebo ženských motivací a schopností. Zřejmý je zde předpoklad odlišných životních agend, jichž má být „,centrum pohlavní identity“ původcem a tyto hračky předobrazem: agendy muže soupeřícího ve veřejné sfére o zdroje, muže-technického odborníka a agendy ženy-pečovatelky a ženy-objektu pro muže. Právě poukazem na preferenci hraček a her přisuzovaných obvykle „opačnému“ „pohlaví “ bývají tradičně uváděny také príběhy transsexuálů/ek v médiích. Ačkoli výběr hraček je možno chápat jako relevantní doklad utvořené - avšak stále se také přetvářející - genderové identity, esencializace těchto voleb, prezentace výběru jistých her a hraček jako nezvratného důkazu transsexuality zároveň petrifikuje proměnlivé genderové konvence a normy a patologizuje překračování aktuálních hranic maskulinity a femininity.

Dalším diagnostickým vodítkem vztahujícím se k životní fázi dětství je preference kolektivu toho pohlaví, s nímž se žadatel/ka o chirurgickou přeměnu identifikuje, a odmítání pohlaví „opačného“ (Procházka a Weiss 2002, Zvěrina 1994). I samotné dětské sbližování $\mathrm{s}$ př́slušníky/cemi druhého pohlaví je však v sexuologii vnímáno jako něco, co si zasluhuje „zdvižení prstu“ - kromě signálu „poruchy“ genderové identity se může jednat, jak tvrdí Zvěřina (1994), také o signál „poruchy“ sexuální „orientace“. Uplatňuje se zde tedy zřejmě předpoklad, že prátelství má vycházet ze „stejnosti“, přičemž se očekává, že tato „stejnost“ je 
indukována př́slušností ke stejnému pohlaví. Pohlavní „opačnost“ má pak nalézt své uplatnění až v aktech reprodukce.

Sexuologie však stanovuje věkovou hranici, před jejímž dosažením ještě není překračování genderových konvencí a norem vztahujících se $\mathrm{k}$ hračkám, hrám a prátelství vnímáno jako jednoznačný příznak patologie. „Ontogeneticky předpokládáme schopnost uvědomit si a vyjádřit svou pohlavní identitu $\mathrm{v}$ předškolním věku, obvykle před čtvrtým rokem života“ (Procházka a Weiss 2002: 14). Po jejím dosažení je ale nonkonformita v těchto oblastech sexuologií nahlížena již jako ,přechod mezi zdravotní poruchou a normálním stavem“ a indikátor možné budoucí transsexuality či homosexuality (Procházka 2002).

\section{„Normální" muž a „,normálni“" žena}

Při zkoumání období dospělosti se diagnostická pozornost přesouvá k preferovaným aktivitám a k oblasti denního snění. Zjišstuje se, zda žadatelé/ky o chirurgickou přeměnu vystupují v těchto sférách v takových rolích, které odpovídají „pohlavi““, jehož tělesné znaky chtějí získat (Weiss, Fifková a Procházka 2002). „Vybírají si obvykle profese typické pro pohlaví, s nímž se identifikují - FtM [female-to-male - pozn. J. D.] pracují často jako př́slušníci policie či bezpečnostních služeb [...], řidiči či montéri, MtF pak jako prodavači, cukráři atd. [...] Psychickou identitou se ř́dí i jejich zájmy - zatímco MtF klienti se zajímají o módu a kosmetiku, FtM např. o kopanou. FtM odmítají taneční, MtF nechtějí na vojnu“ (Weiss, Fifková a Procházka 2002: 33). Stejně jako v př́ípadě hraček a her zde sexuologie čerpá z konkrétní kulturní empirie, z profesí a zájmů, které si muži a ženy v dané kultuře obvykle volí, a vytváŕi kauzální vztah mezi jistým způsobem vyvinutým „centrem pohlavní identity“ a vykonávanými aktivitami. Pro příznaky esenciálního mužství či ženství se však navíc obrací ke krajním pólům kulturního spektra maskulinity a femininity, pro což může nacházet oporu právě ve zkušenostech s některými transsexuály/kami, jejichž volby zaměstnání či zájmy tyto krajní póly (např́klad v důsledku obtížněji získávaného uznání kýžené genderové identity) skutečně obsazují.

Jsou-li však preferované aktivity a role ustaveny jako diagnostické kritérium, zjevně existují také způsoby jednání, které podle sexuologů/žek má nebo naopak nemá „patřičný“ muž a „patřičná“ žena ztělesňovat. Splňovat toto kritérium tedy předpokládá být v souladu s aktuálními genderovými konvencemi, normami či stereotypy.

\section{Postoje $k$ tělu a preference oděvu}

Uvádí se, že transsexualové/ky se ve snech a fantaziích většinou vyskytují v těle, s jehož „pohlavím“ se identifikují, že pocit’ují odpor k primárním a sekundárním pohlavním znakům svého těla, jenž se odráží také v jejich sexualitě, kdy se snaží volit takové aktivity, při nichž nedojde $\mathrm{k}$ uplatnění jejich mužských nebo ženských pohlavních atributů. V sexuálních představách vystupují jako př́slušníci/e toho „pohlavi“", s nímž se identifikují (Weiss, Fifková a Procházka 2002). Tyto rysy představují další z kritérií, na něž se sexuologové/žky v transsexuálních př́bězích zaměřují, přičemž předpokládají, že popisované pocity a fantazie vycházejí z nesouladu mezi vývojem mozku a těla, z reflexe signálů z „centra pohlavní identity“, že tělo, v němž se nachází, je nesprávné. 
Je-li však taktéž přístup k tělu určován dostupnými kulturními zdroji, lze tyto aspekty genderové identity vyložit spíše jako důsledek rozporu mezi pocit’ovanou identitou a identitou okolím prripisovanou. Pohlavní znaky jsou z tohoto hlediska znaky v pravém slova smyslu - určují, prostřednictvím jakých významů jsme čteni/y, což, jak ukazují West a Zimmerman (1987), strukturuje veškeré interakce, do nichž vstupujeme. Jsou nesmazatelným nápisem, od něhož se odvíjí naše existence. Odpor k pohlavním atributům těla může být tedy z tohoto hlediska interpretován jako odpor k významům, jež jsou k mužskému/ženskému tělu v dané kultuře přiřazovány, jako důsledek rozporu mezi zpơsoby, jimiž jsem čten/a okolím a jimiž vnímám sebe sama. Představy, v nichž transsexuální lidé vystupují v těle, jehož pohlavní znaky chtějí získat, jakož i sama touha po chirurgické přeměně pak mohou být chápány jako projev touhy být čten/a jistým způsobem, spojit pocit’ované označované s kulturně patřičným označujícím.

Jednu ze strategií, jak alespoň do jisté míry ovlivnit to, prostřednictvím jakých významů jsem nahlížen/a, představuje výběr šatníku, na čemž se zakládá další sledované diagnostické kritérium - preference oděvu „opačného“ „pohlaví" (Weiss, Fifková a Procházka 2002). Také toto kritérium však předpokládá zapojení představ ohledně toho, co jsou „správné“ a naopak ,špatné“، volby.

\section{III. Imperativ „heterosexuality“}

Součástí transsexuálního prríběhu, jíž je $\mathrm{v}$ procesech diagnózy věnována mimořádná pozornost, je kritérium „heterosexuality“ (Weiss, Fifková a Procházka 2002). Za transsexuální heterosexualitu je pak v sexuologii považován stav, kdy se zamilovanost a sexuální touha váže k osobám téhož anatomického pohlaví. Tuto reklasifikaci iniciovala zkušenost, že většina transsexuálů/ek vystupuje ve svých sexuálních představách jakožto osoba ,pohlaví“, s nímž se identifikuje, a prožívá se v heterosexuálních významech (srov. Skoblík 2006). Převaha „heterosexuality“, sociologicky interpretovatelná jako důsledek spjatosti internalizovaných kulturních koncepcí femininity a maskulinity s heterosexuálními konotacemi těchto pojmů, byla nejprve pojata jako „logický“ dopad „opačně“ vyvinutého „centra pohlavní identity“, v důsledku čehož získala ,heterosexualita“ u transsexuáli̊/ek normativní závaznost.

Ještě v 70. letech byla „heterosexualita“ pro uznání diagnózy transsexuality podmínkou naprosto klíčovou (srov. Procházka a Weiss 2002, Standardy 2002). Následné formulování hypotézy postulující dvě odlišná centra, „centrum pro pohlavní identitu“ a „centrum pro sexuální orientaci“, jež se utvářejí v rozdílné fázi prenatálního vývoje, z důvodu čehož mohou být v zásadě poškozena obě - jakkoli k tomu dochází pouze výjimečně - (Zvěřina 1994), lze pak chápat také jako důsledek snahy legitimizovat existenci transsexuálních osob, které normu „,heterosexuality“ nesplňují. Obecnější implikací tohoto kroku je však zároveň rozpojení předpokládané kauzality mezi jistým ,pohlavím“ s jeho očekávanými projevy (genderem) a podobou sexuální touhy.

Ač nově rozlišovaná kategorie „homosexuální“ transsexuality zmírňuje diagnostický imperativ „heterosexuality“, ,homosexualita“ má vždy - vzhledem k postulované výjimečnosti výskytu - moc zpochybnit diagnózu transsexuality. $Z$ pozice sexuologie prripomíná 
možnost jiného původu touhy po chirurgické přeměně, než je předpokládané „opačně“ vyvinuté ,centrum pohlavní identity“.

Druhá tvář imperativu heterosexuality se pak projevuje v pečlivosti, s níž se sexuologie snaží odlišit („heterosexuální“) transsexualitu od homosexuality, což je, jak uvádí Procházka (2002), dalším z úkolů diferenciální diagnostiky. Předpoklad esenciální rozdílnosti mezi těmito (na počátku 20. století rozpojenými) kategoriemi se odráží v diagnostickém soustředění na míru, $v$ níž se vyšetřovaná osoba ztotožňuje s heterosexualitou, tj. míru, v níž si při sexuálních aktivitách představuje sebe sama jakožto př́slušníka/ci „opačného“ „pohlaví“. Rovněž v tomto př́padě je úsilí stanovit jasnou hranici mezi homosexualitou a transsexualitou motivováno obavou, že by touhu po chirurgické přeměně mohl zapříčiňovat jiný důvod, než předpokládané „opačně“ strukturované mozkové centrum - např́klad úmysl homosexuálů/leseb dosáhnout heterosexuality nebo jejich neujasněnost situace (srov. Zvěřina 1994, Procházka 2002). S cílem stanovit diagnózu co nejpřesněji se sexuologie obrací k př́stroji. Pomoci určit, o kterou ze dvou předpokládaně zcela odlišných tělesných pravd se v daném př́ípadě jedná, má doporučené phaloplethysmografické/volvoplethysmografické vyšetření založené na měření změn prokrvení genitálií $\mathrm{v}$ závislosti na předkládaných vizuálních a auditivních podnětech s homosexuální nebo heterosexuální erotickou tematikou (Brzek 1999; Weiss, Fifková a Procházka 2002a).

\section{Závèr}

Bylo-li gender medicínou konceptualizováno jakožto důsledek pohlavních tělesných atributı̊, príimout situaci „opačné“ genderové sebeidentifikace jako reálnou znamenalo z pozic lékařského oboru, jímž sexuologie je, pojmout transsexualitu jako nemoc či poruchu, která tyto tělesné atributy zasahuje. Postulováním další a zároveň i nejmocnější substance - specifického mozkového centra, jež má genderové projevy generovat a jež se může $\mathrm{v}$ důsledku jistých patologických procesů $\mathrm{v}$ těle plodu vyvíjet „opačně“ vůči ostatním pohlavním atributům těla - sexuologie dále rozvinula esencializující logiku, kterou ve výkladu genderové diference nastolila medicína.

Zavedením transsexuality jakožto diagnostické kategorie a definováním transsexuality jako organické poruchy se však restrukturovalo také uvažování o genderu i jeho prožívání. Patologizovala se místa přestupu genderových hranic a uzavřely se možnosti způsobů bytí. „Je možno říci a nutno ř́́ci, že diagnóza je cestou k úlevě od utrpení, a je možno a nutno říci, že diagnóza zesiluje ono utrpení, které si vyžaduje úlevu“ (Butler 2004: 100).

Ve snaze nalézt konkrétní kritéria, jejichž prostřednictvím by bylo možno „pohlavi““ vzpírající se objektivním měřením diagnostikovat, se sexuologie obrátila k současným genderovým konvencím a normám sexuality. Tyto normy a konvence, jejichž míru osvojení diagnostický proces zjišt’uje, normy a konvence, jimž však plně neodpovídají ani životy „normálních“, ani těch, kteří/ré percipují život v daném pohlavním těle jako nesnesitelný a usilují o chirurgickou přeměnu, pak sexuologie označuje za důsledek mužské či ženské esence, jistým způsobem vyvinutého „,entra pohlavní identity“. V důsledku své vědecké autority sexuologie nastoluje tyto diskurzy jako diskurzy pravdy, čímž značně posiluje jejich normativní 
aspekty - vymezuje souřadnice, uvnitř kterých lze žít žitelné životy, a patologizuje jednání, které je vůči nim nonkonformní.

Vzhledem k formativním účinkům sexuologických diskurzů tedy nelze pojímat existenci transsexuality jakožto diagnostické kategorie i formy konceptualizace transsexuality jako záležitost, která se týká pouze těch, kteří/ré transsexualitu osobně zakoušejí, a těch, kteří/ré ji „léčí“. Jelikož však není důvodu předpokládat, že se v dohledné době výrazně naruší ustavené spojení mezi genderem a anatomickým pohlavím, od chirurgických a hormonálních řešení poskytujících úlevu před normativními tlaky, které si „správné“ vtělení tohoto spojení vyžadují, upustit nelze. I přes vzrůstající dostupnost plastické chirurgie zřejmě ani nelze předpokládat, že by prrístup $\mathrm{k}$ hormonálním přípravkům a operacím tohoto typu mohl být umožněn jinak, než právě skrze diagnózu. Avšak vzhledem k tomu, že touha po chirurgické přeměně je ve většině případů prostředkem eliminace stavů pocit'ovaných jako nesnesitelných, zbavit transsexualitu diagnózy a s ní také finančního krytí patřičných výkonů ze strany zdravotních pojišt'oven by z tohoto úhlu pohledu ani nebylo žádoucí.

Jako utopická se však jeví být také představa, že se změní substancionální chápání transsexuality na straně sexuologie, že dojde k nové rekonceptualizaci původců a zdrojů transsexuality, nebot' současný stav je stavem pro všechny přímo zúčastněné - transsexuály/ky i sexuology/žky - v zásadě vyhovujícím. Přitom by však právě taková rekonceptualizace transsexuality, která by tento fenomén zbavila jeho substancionálních konotací a zároveň udržela zkušenost jeho relativní neměnnosti a volní neovlivnitelnosti, mohla přispět k rozvolnění kulturního sepnutí těla a genderu.

\section{Literatura}

BENJAMIN, Harry. The Transsexual Phenomenon. (1966) 1999. [cit. 20.8. 2007]. Dostupné na: http://www.symposion.com/ijt/benjamin/index.htm

BERGER, Peter L.; LUCKMANN, Thomas. Sociálni konstrukce reality. 1. vyd..Brno: CDK, 1999. 216 s. ISBN 8085959461.

BRZEK, Antonín. Sexuologie pro právníky. Praha: Karolinum, 1999. 70 s. ISBN 8071843830.

BULLOUGH, Vern L. Science in the Bedroom. A History of SexResearch. 1994. [cit.15.4.2007]. Dostupné na: http://www2.huberlin.de/sexology/GESUND/ARCHIV/LIBRO.HTM.

BUTLER, Judith. Trampoty s rodom. Feminismus a podrývanie identity. Bratislava: Aspekt, 2003. 220 s. ISBN 8085549417.

BUTLER, Judith. Undoing Gender. New York: Routledge, 2004. 273 s. ISBN 0415969239.

CAPLAN, Pat. (ed.) The Cultural Construction of Sexuality. London, New York: Routledge, 1991. ISBN 0415040132.

Diskuse. Translidé : Záznam ze sympozia O soudně-lékařských otázkách transsexualismu [online]. 1969. [cit. 12. 12. 2006]. Dostupné na: http://www.translide.cz/books/symposium/ diskuse/_seznam.htm

DOBROTKA, Gustav. Transsexualismus a osobnost. Př́spěvek přednesený na sympoziu O soudně-lékařských otázkách transsexualismu. 1969. [cit. 12. 12. 2006]. Dostupné na: http://www.translide.cz/books/symposium/dobrotka/01.html 
FAUSTO-STERLING, Anne. Sexing the Body. Gender Politics and the Construction of Sexuality. New York: Basic Books, 2000. ISBN 0465077145.

FEINBERG, Leslie. Pohlavní štvanci. Od Johanky z Arku až po současnost. Praha: G plus G, 2000. 173 s. ISBN 8086103323.

FIFKOVÁ, Hana. 2001. Transsexualita z pohledu sexuoložky. Gender, rovné př́ležitosti, výzkum, 2001, č. 3, s. 2-3. ISSN 1213-0028.

FIFKOVÁ, Hana. Základní etapy procesu přeměny pohlaví. In JAROLÍM, L., VESELÝ, J., WEISS, V. (eds.) Transsexualita. Diagnostika a léčba. 1. vyd. Praha : Grada Publishing, 2002a, s. 43-51. ISBN 8024703335.

FIFKOVÁ, Hana. Psychoterapie v procesu přeměny pohlaví. 2002b. [cit. 12. 12. 2006]. Dostupné na: http://www.translide.cz/psychoterapie? $\mathrm{a}=\mathrm{srch}$

FIFKOVÁ, Hana. Transsexualita není nemoc. 2004. [cit. 12. 12. 2006]. Dostupné na: http:// www.translide.cz/nemoc? $\mathrm{a}=$ srch

FIFKOVÁ, Hana ; WEISS, Petr. Etiologie transsexuality. In JAROLÍM, L., VESELÝ, J., WEISS, V. (eds.) Transsexualita. Diagnostika a léčba. 1. vyd. Praha : Grada Publishing, 2002a. s. 21-26. ISBN 8024703335.

FOUCAULT, Michel. Power/Knowledge. 1. vyd. Harlow: Pearson Education Limited, 1980. ISBN 0394513576.

FOUCAULT, Michel. Diskurs, autor, genealogie. 1. vyd. Praha: Nakladatelství Svoboda, 1994. 115 s. ISBN 8020504060.

FOUCAULT, Michel. Dějiny sexuality I. Vưle k vědění. Praha: Hermann \& synové, 1999. 189 s. FOUCAULT, Michel. Myšlení vnějšku. 2. vyd. Praha: Hermann \& synové, 2003. 303 s.

HYNIE, Josef. O soudně-lékařských otázkách transsexualismu. Př́spěvek přednesený na sympoziu O soudně-lékařských otázkách transsexualismu. 1969. [cit. 12. 12. 2006]. Dostupné na: http://www.translide.cz/books/symposium/hynie/01.html

HYNIE, Josef. Základy sexuologie I. 2. vyd. Praha : Univerzita Karlova, 1980.

KESSLER, Suzanne J. ; McKENNA, Wendy. Gender: An Ethnomethodological Approach. Chicago: The University of Chicago Press, 1985. 233 s. ISBN 0226432068.

KLAUSOVÁ, K. Kouzelnice s pohlavími (rozhovor s Růženou Hajnovou). [cit. 12. 12. 2006]. 2001. Dostupné na: http://translide.unas.cz/?116\&PHPSESSID=c8b656f1290e584bc 3 eb63527a33ccf8

LAQUEUR, Thomas. Making sex: Body and Gender from the Greeks to Freud. Cambridge, Massachusetts, London: Harvard University Press, 1990. ISBN 0674543556.

MAREŠOVÁ, M. ; WEISS, Petr. Několik poznámek k problematice transsexualismu. Československá psychologie, 1998, č. 4, s. 306-312. ISSN 0009062X.

MOLČAN, Ján. ; BARDOŠ, Augustín. Vybrané kapitoly zo sexuológie a hraničných odborov. Martin: Osveta, 1989.

NEORAL, Lubomír. K soudně-lékařské problematice kastrace při transsexualismu. Př́spěvek přednesený na sympoziu O soudně-lékařských otázkách transsexualismu. 1969. [cit. 12. 12. 2006]. Dostupné na: http://www.translide.cz/books/symposium/neoral/01.html

PFÄFFLIN, Friedemann. Sex Reassignment, Harry Benjamin, and some European Roots. [online]. 1997, IJT 1(2). [cit. 3. 8. 2007]. Dostupné na: http://www.symposion.com/ ijt/ijtc0202.htm 
PROCHÁZKA, Ivo. Diferenciální diagnostika. In JAROLÍM, L., VESELÝ, J., WEISS, V. (eds.) Transsexualita. Diagnostika a léčba. 1. vyd. Praha : Grada Publishing, 2002. s. 37-42. ISBN 8024703335.

PROCHÁZKA, Ivo ; WEISS, Petr. Pohlavní identita. In JAROLÍM, L., VESELÝ, J., WEISS, V. (eds.) Transsexualita. Diagnostika a léčba. 1. vyd. Praha : Grada Publishing, 2002. s. 13-20. ISBN 8024703335.

ROZMARIČ, Adolf. Transsexualismus z hlediska soudně-lékařského. Př́spěvek přednesený na sympoziu O soudně-lékařských otázkách transsexualismu. 1969. [cit. 12. 12. 2006]. Dostupné na: http://www.translide.cz/books/symposium/rozmaric/01.html

SKOBLÍK, Jiří. Transsexualismus. 1. vyd. Praha: Karolinum, 2006. 212 s. ISBN 8024610523.

Standardy péče pro poruchy pohlavní identity, šestá verze. In JAROLÍM, L., VESELÝ, J., WEISS, V. (eds.) Transsexualita. Diagnostika a léčba. 1. vyd. Praha : Grada Publishing, 2002. s. 131-158. ISBN 8024703335.

WEEDON, Chris. Feminist Practice and Poststructuralist Theory. Oxford: Basil Blackwell, 1987. ISBN 0631198253.

WEISS, Petr ; FIFKOVÁ, Hana ; PROCHÁZKA, Ivo. Diagnostika transsexuality. In JAROLÍM, L., VESELÝ, J., WEISS, V. (eds.) Transsexualita. Diagnostika a léčba. 1. vyd. Praha : Grada Publishing, 2002. s. 27-36. ISBN 8024703335.

WEISS, Petr ; FIFKOVÁ, Hana ; PROCHÁZKA, Ivo. Rozdíly mezi transsexuály FtM a MtF. In JAROLÍM, L., VESELÝ, J., WEISS, V. (eds.) Transsexualita. Diagnostika a léčba. 1. vyd. Praha : Grada Publishing, 2002b. s. 91-100. ISBN 8024703335.

WEST, Candace ; ZIMMERMAN, Don H. Doing Gender. Gender and Society, 1987, č.2, s. 125-151. ISSN 08912432.

WIDERMANNOVÁ, Libuše. Naše zkušenosti s transsexualismem. Př́spěvek přednesený na sympoziu O soudně-lékařských otázkách transsexualismu. 1969. [cit. 12. 12. 2006]. Dostupné na: http://www.translide.cz/books/symposium/widermannova/01.html

ZVĚ̌̌INA, Jaroslav. Lékařská sexuologie. 1. vyd. Praha: Schering Pharma, 1994. 233 s. ISBN 8085467046.

\section{Autorka}

Jana Dvořáčková je absolventkou magisterského programu sociologie na Fakultě sociálních studií MU. Zde otištěný text je částí její diplomové práce. V současnosti studuje sociologii v doktorském studijním programu téže fakulty.

Kontakt: dvoracko@fss.muni.cz 